\title{
FAKTOR-FAKTOR YANG MEMPENGARUHI PENGUNGKAPAN CORPORATE SOCIAL RESPONSIBILITY DI DALAM LAPORAN SUSTAINABILITY (Studi Empiris Pada Perusahaan yang listing di Bursa Efek Indonesia Tahun 2010-2013)
}

\author{
Dita Rohmah \\ Kementrian Agama RI Dirjen PHU \\ dita011@yahoo.com
}

\begin{abstract}
Absract. The study aims to examine the effect of corporate governance, firm size, and profitability to corporate social responsibility disclosure in sustainability report. The mechanism of corporate governance used are independent commissioner, institutional ownership, and foreign ownership. This research is a quantitative study using scientific research in the form of positive economics. The nature and type of this research is descriptive with the method used by literature survey. Data used is secondary data obtained from www.idx.co.id and corporate websites. The analytical method used is multiple linear regression analysis with SPSS version 22. The populations in this study are all companies listed on the Indonesia Stock Exchange during the period 2010 until 2013. Samples are taken by purposive sampling method amount 21companies with 4 years observation. Based on the results of multiple regression analysis with a significant level of 5\%, the results of this study concluded that: (1) Independent Commissary does not signicantly influence the effect on the disclosure of CSR in the sustainability report with the significant value $0.390>0.05$. (2) Institutional Ownership has a significant effect on the disclosure of CSR in the sustainability report with the significant value $0.003<0.05$. (3) Foreign Ownership does not signicantly influence the effect on the disclosure of CSR in the sustainability report with the significant value $0.221>0.05$. (4) Firm Size has a significant effect on the disclosure of CSR in the sustainability report with the significant value $0.000<0.05$. (5) Profitability has a significant effect on the disclosure of CSR in the sustainability report with the significant value 0.001<0.05.
\end{abstract}

Keywords: Independent Commissioner, Institutional Ownership, Foreign Ownership, Firm Size, Profitability, Corporate Social Responsibility Disclosure, Sustainability Report

Abstrak. Penelitian ini bertujuan untuk menguji pengaruh mekanisme corporate governance, ukuran perusahaan, dan profitabilitas perusahaan terhadap pengungkapan corporate social responsibility di dalam laporan sustainability. Mekanisme corporate governance yang digunakan adalah dewan komisaris independen, kepemilikan institusional, dan kepemilikan asing. Penelitian ini merupakan jenis penelitian kuantitatif dengan menggunakan penelitian keilmuan berupa ekonomi positif. Sifat dan jenis dari penelitian ini adalah deskriptif dengan metode yang digunakan berdasarkan survei literatur. Jenis data yang digunakan adalah data sekunder yang diperoleh dari www.idx.co.id dan website perusahaan. Metode analisis yang digunakan adalah analisis regresi linier berganda dengan bantuan software SPSS versi 22. Populasi dalam penelitian ini adalah seluruh perusahaan yang terdaftar di Bursa Efek Indonesia selama periode 2010 sampai 2013. Sedangkan sampel penelitian ini ditentukan dengan menggunakan metode purposive sampling sehingga diperoleh 21 perusahaan sampel dengan pengamatan selama 4 
tahun. Berdasarkan hasil analisis regresi berganda dengan tingkat signifikansi 5\% maka hasil penelitian ini menyimpulkan: (1) Dewan komisaris independen tidak berpengaruh signifikan terhadap pengungkapan CSR di dalam laporan Sustainability dengan nilai signifikansi $0.390>0.05$. (2) Kepemillikan institusional berpengaruh signifikan terhadap pengungkapan CSR di dalam laporan sustainability dengan nilai signifikansi $0.003<0.05$. (3) Kepemilikan asing tidak berpengaruh signifikan terhadap pengungkapan CSR dalam laporan sustainability dengan nilai signifikansi $0.221>0.05$. (4) Ukuran perusahaan berpengaruh signifikan terhadap pengungkapan CSR di dalam laporan sustainability dengan nilai signifikansi $0.000>0.05$, dan (5) Profitabilitas berpengaruh signifikan terhadap pengungkapan CSR di dalam laporan sustainability dengan nilai signifikansi $0.001>0.05$.

Kata kunci: Dewan Komisaris Independen, Kepemilikan Institusional, Kepemilikan Asing, Ukuran perusahaan, Profitabilitas, Corporate Social Responsibility Disclosure, Sustainability Report.

\section{PENDAHULUAN}

Perusahaan yang tumbuh dan berkembang mempunyai tujuan utama yaitu profitabilitas dengan mendapatkan pencitraan dan persepsi yang baik dari para stakeholder. Namun dewasa ini pandangan tersebut bergeser kearah yang lebih kompleks yaitu bagaimana masyarakat sebagai pengguna hasil produksi perusahaan mengakui kredibilitas perusahaan tersebut. Sebab, perusahaan merupakan bagian dari masyarakat dan lingkungan yang keberadaannya tidak lepas darinya. Mengingat hal tersebut maka penting bagi perusahaan untuk turut serta menjaga dan peduli terhadap aspek sosial baik masyarakat maupun lingkungan dimana perusahaan tersebut beroperasi. Konsep ini kemudian berkembang dengan istilah Corporate Sosial Responsibility (CSR). CSR dimaksudkan untuk mendorong dunia usaha lebih etis dalam menjalankan aktivitasnya agar tidak berdampak buruk pada masyarakat dan lingkungan hidupnya, sehingga pada akhirnya dunia usaha akan dapat bertahan secara berkelanjutan (Kusuma et al. 2014:2). CSR adalah salah satu faktor penting untuk meningkatkan nilai perusahaan, maka perusahaan perlu mempertimbangkan CSR sebagai salah satu aspek daya tarik bagi investor selain kinerja keuangan perusahaan. Investor cenderung tertarik terhadap informasi sosial yang dilaporkan dalam laporan keuangan, dimana pelaporan keuangan merupakan media bagi manajemen perusahaan dalam memberikan informasi kinerja keuangan entitas yang bermanfaat untuk stakeholders. Selain pelaporan keuangan sebagai media pengungkapan tanggung jawab perusahaan, perkembangan pelaksanaan CSR mendorong perusahaan untuk juga mengungkapkan sebuah laporan yang tidak hanya 
berpijak pada kondisi keuangan saja tetapi juga menyediakan informasi lingkungan dan sosial yang kemudian disebut laporan berkelanjutan atau sustainability report (Ratnasari, 2011:2)

Secara definisi sustainability report adalah praktek pengukuran, pengungkapan dan upaya akuntabilitas dari kinerja organisasi dalam mencapai tujuan pembangunan berkelanjutan kepada para pemangku kepentingan baik internal maupun eksternal (http://www.globalreporting.org, di akses pada 12 Januari 2015). Sustainability report ini disusun berdasarkan pedoman dari Global Reporting Initiative (GRI) yang telah dikembangkan sejak tahun 1990 dan disusun tersendiri terpisah dari laporan keuangan atau laporan tahunan. Dalam penelitian ini item pengungkapan tanggung jawab sosial diukur berdasarkan 9 indikator kinerja ekonomi, 30 indikator kinerja lingkungan, dan 40 indikator kinerja sosial yang dikeluarkan oleh GRI. Kasus-kasus tersebut memberikan gambaran bahwa perusahaan sesungguhnya juga perlu memperhatikan sisi non keuangan terutama dari sisi lingkungan dan sosial. Untuk itu, perusahaan harus mulai menyadari untuk mendorong praktik pengungkapan tanggung jawab sosial serta memenuhi tuntutan akan penerapan good corporate governance dalam rangka pengelolaan perusahaan yang baik. Praktik dan pengungkapan Corporate Social Responsibility (CSR) merupakan konsekuensi logis dari implementasi Good Corporate Governance (GCG), yang prinsipnya antara lain menyatakan bahwa perusahaan perlu memperhatikan kepentingan stakeholder-nya, sesuai dengan aturan yang ada dan menjalin kerjasama yang aktif dengan stakeholder demi kelangsungan hidup jangka panjang perusahaan. Pengaturan dan pengimplementasian GCG memerlukan komitmen dari seluruh jajaran organisasi, dimulai dengan penetapan kebijakan dasar dan tata tertib yang dianut oleh top manajemen serta penerapan kode etik yang dipatuhi oleh semua pihak yang ada di dalamnya. Apabila sistem Corporate Governance yang terdiri atas struktur Corporate Governance (pemegang saham, dewan komisaris, dewan direksi, komite audit, sekertaris perusahaan, manajer dan karyawan, auditor) dilaksanakan dengan mekanisme yang baik dan dilandasi dengan prinsip Corporate Governance, maka akan bermanfaat dalam mengatur dan mengendalikan perusahaan. Selain itu mekanisme dan struktur Governance perusahaan dapat dijadikan sebagai pendukung terhadap praktik dan pengungkapan CSR di Indonesia (Utama dalam Cahyaningsih 
dan Martina, 2011:173). Dari penjelasan di atas menunjukan bahwa aktivitas CSR tidak bisa terlepas dari penerapan GCG. Pada penelitian kali ini, penerapan Corporate Governance akan dilihat melalui mekanismenya yang diproksikan dengan komposisi dewan komisaris independen, kepemilikan institusional dan kepemilikan asing serta profitabilitas dan ukuran perusahaan terhadap tingkat pengungkapan CSR di dalam laporan Sustainability.

Komisaris independen adalah komisaris yang bukan merupakan anggota manajemen, pemegang saham mayoritas, pejabat atau berhubungan langsung maupun tidak langsung dengan pemegang saham mayoritas dari suatu perusahaan tersebut (Surya dan Yustiavandana, 2006: 135). Dengan adanya dewan komisaris independen diharapkan dapat memberikan tekanan pada perusahaan untuk mengungkapkan sustainability report dalam rangka memastikan keselarasan antara keputusan dan tindakan perusahaan dengan nilai-nilai sosial dan legitimasi perusahaan (Ratnasari, 2011:9).

Kepemilikan institusional umumnya merupakan pemegang saham yang cukup besar karena memiliki pendanaan yang besar. Tingkat kepemilikan institusional yang tinggi menimbulkan usaha pengawasan yang lebih besar untuk menghalangi perilaku opportunistic manajer (Rustiarini, 2010:7).

Kepemilikan asing (foreign ownership) adalah jumlah saham yang dimiliki oleh pihak asing (luar negeri) baik oleh individu maupun lembaga terhadap saham perusahaan di Indonesia. Selama ini kepemilikan oleh pihak asing merupakan pihak yang dianggap concern terhadap pengungkapan CSR (Sari, 2014:6).

Profitabilitas adalah kemampuan perusahaan dalam menghasilkan laba atau profit. Semakin tinggi tingkat profitabilitas perusahaan maka semakin besar pengungkapan informasi sosial. Ukuran perusahaan dapat diartikan sebagai suatu skala pengklasifikasian besar kecilnya suatu perusahaan atau organisasi yang didirikan oleh seseorang atau lebih untuk mencapai tujuannya.

Penelitian yang terkait dengan Corporate Governance, ukuran perusahaan, profitabilitas dan pengungkapan Corporate Social Responsibility oleh perusahaan telah dilakukan oleh beberapa peneliti terdahulu. Hal ini menunjukkan bahwa penerapan Corporate Governance, ukuran perusahaan, profitabilitas dan pengungkapan Corporate Social Responsibility merupakan hal yang penting dan 
membutuhkan perhatian besar. Secara umum, objek penelitian dalam penelitian tersebut merupakan perusahaan manufaktur dan perbankan. Penelitian tersebut antara lain telah dilakukan oleh Sari et al. 2013; Sriayu dan Mimba, 2013; Komalasari, 2014; Trisnawati, 2014.

Penelitian yang dilakukan oleh Komalasari (2014) yang membahas mengenai pengaruh mekanisme corporate governance, ukuran perusahaan dan profitabilitas perusahaan terhadap luas pengungkpan corporate social responsibility menunjukkan hasil bahwa yang mempengaruhi mekanisme corporate governance terhadap luas pengungkapan corporate social responsibility hanyalah ukuran perusahan saja, selebihnya tidak berpengaruh signifikan. Sementara itu studi yang dilaksanakan Trisnawati (2014) tentang pengaruh ukuran perusahaan, profitabilitas, leverage, ukuran dewan komisaris dan kepemilikan manajerial terhadap pengungkapan corporate social responsibility (CSR) industri perbankan di Indonesia menunjukkan hasil bahwa hanya ukuran perusahaan yang mempengaruhi pengungkapan corporate social rensponsibility.

Berbeda dengan penelitian Sari et al. (2013) yang menunjukkan hasil bahwa yang mempengaruhi terhadap luas pengungkapan Corporate Social Responsibility adalah kepemilikan institusional, ROE dan ROA. Sedangkan komposisi dewan komisaris dan ukuran perusahaan tidak memiliki pengaruh terhadap luas pengungkapan corporate social renspobility. Begitu juga dengan penelitian yang dilakukan Sriayu dan Mimba (2013) yang menyatakan bahwa company size, foreign ownership dan public ownership berpengaruh positif dan signifikan terhadap Corporate Social Responsibility Disclosure.

\section{METODOLOGI PENELITIAN}

Penelitian ini merupakan jenis penelitian kuantitatif, yaitu membutuhkan pengujian untuk membuktikan kebenaran dari hipotesis yang diajukan. Menurut Indrianto \& Supomo (1999:12), penelitian kuantitatif menitikberatkan pada pengujian teori-teori yang diukur melalui hubungan antar variabel dan dianalisis dengan prosedur stasistik. Pendekatan kuantitatif ini berasal dari data yang diperoleh dari laporan keuangan sehingga data yang diukur dalam suatu skala numeric (angka). Sifat dan jenis dari penelitian ini adalah deskriptif dengan metode yang digunakan berdasarkan survei literatur. Penelitian keilmuan yang digunakan adalah ekonomi 
positif. Penelitian ini bertujuan untuk mengetahui hubungan antara dua variabel, atau bagaimana suatu variabel mempengaruhi variabel yang lain. Populasi pada penelitian ini adalah seluruh perusahaan yang listing di Bursa Efek Indonesia (BEI). Dilihat dari dimensi waktu yang digunakan, penelitian ini termasuk ke dalam kelompok data time series dengan periode penelitian selama empat tahun yaitu tahun 2010 sampai 2013 dengan alasan bahwa pada tahun 2009 telah berlaku Undang-undang No. 40/2007 tentang Perseroan Terbatas yang mewajibkan perseroan dengan bidang usaha di bidang atau terkait dengan bidang sumber daya alam untuk melaksanakan tanggung jawab sosial dan lingkungan.

Jumlah populasi dalam penelitian ini sebanyak 486 perusahaan yang secara konsisten dan terdaftar di BEI pada periode 2010 sampai 2013. Sampel yang diambil adalah perusahaan yang listing di Bursa Efek Indonesia yang dipilih dengan menggunakan metode purposive sampling yaitu salah satu teknik pengambilan sampel Non Probabilistic yang dilakukan berdasarkan kriteria atau pertimbangan tertentu (Indriantoro dan Supomo, 2002:120). Adapun kriteria dalam penentuan sampel yang akan digunakan diantaranya adalah:

1. Perusahaan yang listing di Bursa Efek Indonesia Selama periode 2010 s.d 2013 dan tidak mengalami delisting selama periode pengamatan.

2. Perusahaan mencantumkan laporan pertanggungjawaban sosial dalam annual report maupun sustainability report (SR) selama periode penelitian.

3. Perusahaan memiliki data yang lengkap terkait dengan variabel-variabel yang digunakan selama periode penelitian.

\section{PEMBAHASAN}

\section{Analisis Statistik Deskriptif}

Analisis deskriptif merupakan metode dimana semua data yang berhubungan dengan penelitian dikumpulkan dan dikelompokkan untuk kemudian dianalisis dan diinterprestasikan secara objektif dengan membandingkan nilai minimum, nilai maksimum dan rata-rata dari sampel. Variabel-variabel yang digunakan dalam penelitian ini yaitu dewan komisaris independen, ukuran perusahaan, profitabilitas, kepemilikan institusional, kepemilikan asing sebagai variabel independen. Berikut Tabel merupakan analisis deskriptif untuk variabel yang digunakan dalam penelitian ini. 
Tabel Statistik Deskriptif

\begin{tabular}{|l|r|r|r|r|r|}
\hline & & & & & $\begin{array}{c}\text { Std. } \\
\text { Deviation }\end{array}$ \\
\hline CIS & & Minimum & Maximum & Mean & 0,09601 \\
IOWN & 84 & 0,22 & 0,60 & 0,4340 & 0,0967 \\
FOR & 84 & 0,02 & 0,97 & 0,5538 & 0,27893 \\
SIZE & 84 & 0,00 & 0,97 & 0,4151 & 0,30782 \\
ROE & 84 & 28,42 & 33,59 & 30,7175 & 1,47615 \\
CSR & 84 & $-0,57$ & 0,45 & 0,1547 & 0,12163 \\
Valid N & 84 & 0,25 & 1,00 & 0,7101 & 0,22519 \\
(listwise) & 84 & & & & \\
\hline
\end{tabular}

Sumber: Output SPSS yang diolah.

\section{Hipotesis satu : Pengaruh Dewan Komisaris Independen Terhadap}

\section{Pengungkapan Corporate Social Responsibility di dalam laporan sustainability}

Berdasarkan pengujian yang telah dilakukan, hasil penelitian ini menunjukan bahwa corporate governance dengan proksi dewan komisaris independen (CIS) memiliki nilai $t_{\text {hitung }}-0,084$ dengan tingkat signifikansi sebesar 0,390 dan juga dapat dilihat nilai unstandardized coefficient beta sebesar -0,198. Dengan demikian hipotesis pertama $\left(\mathrm{H}_{1}\right)$ ditolak, artinya dewan komisaris independen tidak berpengaruh terhadap pengungkapan Corporate Social Responsibility. Penelitian ini membuktikan bahwa besarnya proporsi dewan komisaris independen tidak meningkatkan atau mendorong perusahaan untuk melakukan pengungkapan CSR perusahaan di dalam sustainability report.

Hasil penelitian ini konsisten dengan hasil penelitian yang dilakukan oleh Komalasari (2014), Sari (2014), Putri (2013), Ratnasari (2011), Cahyaningsih dan Martina (2011). Hal ini mencerminkan terdapat beberapa hal yang diduga menjadi alasan mengapa besarnya proporsi Dewan Komisaris Independen tidak berpengaruh signifikan terhadap pengungkapan CSR seperti yang dinyatakan oleh (Ratnasari, 2011:21) bahwa proporsi komisaris independen dalam dewan komisaris pada perusahaan sampel masih rendah, sehingga kemampuan komisaris independen dalam memantau perilaku dewan direksi (manajemen) belum maksimal. Hal ini terbukti dari rata-rata jumlah komisaris independen pada perusahaan sebanyak $43,4 \%$ dari total anggota dewan komisaris. 
Selain itu terdapat indikasi kemungkinan pemilihan dan pengangkatan komisaris independen yang kurang efektif dimana komisaris independen tidak dapat menunjukan independensinya sehingga pengawasan tidak dapat berjalan dengan baik. Oleh karena itu, keberadaan dewan komisaris dalam suatu perusahaan belum berpengaruh dalam pemantauan kualitas pengungkapan finansial dan tanggung jawab sosial perusahaan Menurut Terzhagi (2012:44) tidak berpengaruhnya dewan komisaris independen terhadap pengungkapan corporate social responsibility karena adanya kemungkinan bahwa dewan komisaris independen memiliki kompetensi yang lemah. Menurut Restuningdiah (2010:258) kompetensi Dewan Komisaris memegang peranan penting dalam pengambilan keputusan, sehingga bukan hanya komposisi Dewan Komisaris Independen yang dipertimbangkan, namun juga pengetahuan dan latar belakang pendidikan sehingga dapat meningkatkan kualitas pengambilan keputusan pada tingkat komisaris terkait dengan CSR. Hasil penelitian ini juga menunjukan bahwa perusahaan yang memiliki proporsi dewan komisaris independen yang tinggi ternyata memiliki tingkat pengungkapan CSR yang rendah, seperti Bank Negara Indonesia Tbk, Bank Tabungan Negara Tbk, dan Bank Danamon Tbk. Ketiga perusahaan ini telah memiliki dewan komisaris independen diatas 30\%, namun terbukti belum secara konsisten mengungkapkan tanggungjawab sosialnya di dalam laporan sustainability dengan tingkat pengungkapan dibawah 50\% dari seluruh indikator yang ditetapkan GRI. Menurut Siregar dalam Terzaghi (2012:44) ketentuan minimum dewan komisaris independen sebesar 30\% mungkin belum cukup tinggi untuk menyebabkan para komisaris independen tersebut dapat mendominasi kebijakan yang diambil oleh dewan komisaris. Jika pihak komisaris independen merupakan pihak yang mayoritas maka mungkin dapat lebih efektif dalam menjalankan perannya. Oleh karena itu fungsinya sebagai pihak yang bertindak independen dan semata-mata untuk kepentingan perusahan tidak berjalan dengan baik, yang dapat berdampak pada kurangnya dorongan terhadap manajemen untuk melakukan pengungkapan sosial.

Namun, hasil penelitian ini tidak konsisten dengan penelitian yang dilakukan oleh Santioso dan Chandra (2012), Yesika (2013) yang menyatakan bahwa ukuran komisaris independen dianggap sebagai sebuah mekanisme yang dapat diandalkan untuk menghilangkan konflik keagenan antara manajer dan pemegang saham. 
Perusahaan yang memiliki Dewan Komisaris Independen cenderung lebih peka terhadap kinerja sosial dan mencegah tindakan yang menimbulkan pelanggaran lingkungan. Menurut Prasojo dalam (Putri, 2013:18) juga menyatakan bahwa semakin besar persentase anggota independen yang ada pada dewan komisaris akan meningkatkan aktivitas monitoring terhadap kualitas pengungkapan dan mengurangi kepentingan dari kegiatan yang berusaha menutupi informasi.

\section{Hipotesis kedua : Pengaruh kepemilikan institusional Terhadap Pengungkapan}

\section{Corporate Social Responsibility di dalam laporan sustainability}

Berdasarkan pengujian yang telah dilakukan, hasil penelitian ini menunjukan bahwa variabel kepemilikan institusional (IOWN) memiliki $t_{\text {hitung }}$ yaitu $-3,118$ dengan tingkat signifikansinya sebesar 0,003 dan juga dapat dilihat nilai unstandardized coefficient beta sebesar-0,283. Dengan demikian hipotesis kedua $\left(\mathrm{H}_{2}\right)$ diterima, artinya kepemilikan institusional berpengaruh terhadap pengungkapan Corporate Social Responsibility. Hasil penelitian ini tidak konsisten dengan penelitian yang dilakukan oleh Rustiarini (2010), Komalasari (2014), Kusuma et al. (2014) dan Maulidra (2015) yang menemukan bahwa kepemilikan institusional tidak berpengaruh terhadap pengungkapan CSR. Namun penelitian ini konsisten dengan penelitian yang dilakukan oleh Cahyaningsih dan Martina (2011), Setyarini dan Paramitha (2011), Sari et al. (2013), Azhar (2014), dan Purnama et al. (2014) yang menemukan bahwa kepemilikan institusional berpengaruh terhadap pengungkapan CSR.

Hasil penelitian ini membuktikan bahwa kepemilikan saham institusional yang terdapat pada perusahaan-perusahaan yang menjadi sampel penelitian ini yaitu bank, perusahaan manufaktur, perusahaaan konstruksi, perusahaan komunikasi, perusahaan agriculture dan mining yang listing di BEI, memiliki komposisi kepemilikan institusional yang besar. Hal tersebut membuat kemampuan investor institusional dalam memonitor manajemen akan jauh lebih efektif. Hasil penelitian ini juga menunjukan terdapat arah negatif pada hubungan antara kepemilikan institusional dengan pengungkapan corporate social responsibility. Artinya semakin tinggi tingkat kepemilikan saham oleh institusi maka akan mengurangi tingkat pengungkapan CSR yang dilakukan perusahaan. Alasan yang dapat digunakan untuk menjelaskan hal tersebut mungkin dapat terjadi karena semakin banyak saham 
perusahaan yang dimiliki oleh pihak institusi, maka institusi mempunyai peluang untuk melakukan intervensi terhadap jalannya perusahaan serta mengatur proses penyusunan laporan keuangan. Akibatnya manajer terpaksa melakukan tindakan tertentu demi memenuhi keingingan pihak-pihak institusi (Budiono dalam Azhar, 2014:67). Dengan demikian apabila kepemilikan institusi semakin besar, maka pihak institusi hanya memiliki tujuan untuk memaksimalkan keuntungan pribadi saja tanpa mempedulikan tanggung jawab perusahaan pada stakeholders lain.

Menurut Cahyaningsih dan Martina (2011), pihak institusi saat ini kurang peduli dengan pelaksanaan pengungkapan tanggung jawab sosial perusahaan karena investor institusional belum mempertimbangkan tanggung jawab sosial sebagai salah satu kriteria dalam melakukan investasi. Hal tersebut mengakibatkan menurunnya tingkat pengungkapan CSR yang dilakukan perusahaan.

\section{Hipotesis ketiga: Pengaruh kepemilikan Asing Terhadap Pengungkapan Corporate Social Responsibility di dalam laporan sustainability}

Berdasarkan pengujian yang telah dilakukan, hasil penelitian ini menunjukan bahwa variabel kepemilikan asing (FOR) memiliki thitung yaitu 1,233 dengan tingkat signifikansi sebesar 0,221 dan juga dapat dilihat nilai unstandardized coefficient beta sebesar 0,101. Dengan demikian hipotesis ketiga $\left(\mathrm{H}_{3}\right)$ ditolak, artinya kepemilikan asing tidak berpengaruh terhadap pengungkapan Corporate Social Responsibility. Hasil penelitian ini konsisten dengan hasil penelitian yang dilakukan oleh Maulidra (2015), Kusuma et al. (2014) serta Sari (2014), yang menyatakan bahwa tidak adanya hubungan antara kepemilikan saham asing dengan pengungkapan CSR yang mengandung arti bahwa, semakin besar/kecil persentase kepemilikan saham oleh pemegang saham asing pada perusahaan, tidak mempengaruhi luas atau tidaknya tingkat pengungkapan CSR di dalam sustainability report. Tidak signifikannya hasil penelitian ini disebabkan karena rata-rata perusahaan sampel lebih didominasi oleh perusahaan yang tidak memiliki kepemilikan saham asing yang besar tetapi pengungkapan CSR sudah cukup efektif terlaksana sehingga tidak terdapat hubungan yang signifikan antara jumlah presentase kepemilikan saham asing terhadap luas atau tidaknya pengungkapan corporate social responsibility (Maulidra, 2015:21). Lovink (2013) juga menjelaskan alasan mengapa kepemilikan asing dalam perusahaan di Indonesia tidak ada hubungannya dengan pengungkapan CSR yang 
dilakukan perusahaan, hal ini terjadi karena kemungkinan kepemilikan asing pada perusahaan di Indonesia secara umum belum mempedulikan masalah lingkungan dan sosial sebagai isu kritis yang harus secara ekstensif untuk diungkapkan dalam laporan tahunan dan laporan sustainability. Dengan demikian dapat disimpulkan besar atau kecilnya presentase kepemilikan asing di suatu perusahaan tidak dapat mempengaruhi pengungkapan tanggung jawab sosial yang dilakukan oleh perusahaan.

Penelitian ini tidak konsisten dengan penelitian yang dilakukan oleh Putri (2013), Sriayu dan Mimba (2013), Rustiarini (2010), yang menyatakan bahwa kepemilikan asing berpengaruh signifikan terhadap pengungkapan CSR. Hal ini menunjukan bahwa perusahaan yang memiliki kepemilikan asing yang tinggi dianggap mampu menjadikan proses monitoring menjadi jauh lebih baik, yang berdampak pada informasi yang diberikan pihak manajemen kepada stakeholders lebih menyeluruh dan transparan (Sriayu dan Mimba, 2013:339). Hal ini juga menunjukkan bahwa secara umum kepemilikan asing di Indonesia sangat peduli terhadap isu-isu sosial yang ada di Indonesia, seperti pendidikan, kesehatan dan lingkungan.

\section{Hiopotesis keempat: Pengaruh Ukuran Perusahaan Terhadap Pengungkapan Corporate Social Responsibility di dalam laporan sustainability}

Berdasarkan pengujian yang telah dilakukan, hasil penelitian ini menunjukan bahwa variabel ukuran perusahaan (SIZE) memiliki thitung yaitu -5,961 dengan tingkat signifikansi sebesar 0,000 dan dapat dilihat juga nilai unstandardized coefficient beta sebesar -0.090. Dengan demikian hipotesis keempat $\left(\mathrm{H}_{4}\right)$ diterima, artinya ukuran perusahaan berpengaruh terhadap pengungkapan corporate social responsibility, Hasil penelitian ini tidak konsisten dengan penelitian yang dilakukan oleh penelitian Sari et al. (2013), Putri (2013) dan Oktariani (2014) yang menemukan bahwa ukuran perusahaan (size) tidak berpengaruh terhadap pengungkaan CSR. Namun hasil penelitian ini konsisten dengan penelitian yang dilakukan oleh Utami dan Rahmawati (2010), Santioso dan Chandra (2012), Marina (2012), Sriayu dan Mimba (2013), Trisnawati (2014), Komalasari (2014), dan Kusuma et al. (2014) yang menemukan bahwa ukuran perusahaan berpengaruh terhadap pengungkapan corporate social responsibility (CSR). 
Hasil penelitian ini juga menunjukan terdapat arah negatif pada hubungan antara ukuran perusahaan dengan pengungkapan corporate social responsibility. Artinya semakin besar tingkat ukuran perusahaan (size) maka semakin kecil tingkat pengungkapan CSR yang dilakukan perusahaan. Hal tersebut dapat terjadi karena perusahaan besar sudah memiliki kredibilitas yang tinggi di mata publik, sehingga secara tidak langsung juga sudah memiliki legitimasi dari publik. Kondisi ini mengindikasikan bahwa untuk mendapatkan legitimasi dari publik, perusahaan besar tidak akan selalu mengungkapkan tangung jawab sosial yang lebih banyak untuk mempunyai pengaruh dengan pihak-pihak internal maupun eksternal yang berkepentingan di perusahaan. Menurut Marfu'ah dan Cahyo (2011) dalam Arthana (2013:11) hal ini dikarenakan tanggung jawab sosial perusahaan bukan lagi menjadi sekedar kegiatan, tetapi merupakan sebuah kewajiban bagi perusahaan yang berguna untuk menjaga kelangsungan hidup perusahaan. Hal ini dapat dibuktikan dari sampel penelitian ini, yaitu Bank Negara Indonesia Tbk (BBNI) merupakan perusahaan yang memiliki total aset yang selalu meningkat tiap tahunnya. Dimana total asset pada tahun 2013 hingga mencapai Rp.386.654.815.000.000, paling tinggi dari seluruh sampel penelitian. Namun Bank Negara Indonesia Tbk (BBNI) pada tahun 2012 mengungkapkan tanggung jawab sosialnya baru mencapai 49,9\%, kemudian pada tahun 2013 Bank BNI mengalami penurunan dalam mengungkapkan tanggung jawab sosialnya menjadi 39,6\%. Kondisi ini mengindikasikan bahwa perusahaan besar belum terbukti memiliki tingkat pengungkapan CSR yang tinggi.

\section{Hipotesis kelima : Pengaruh Profitabilitas Terhadap Pengungkapan Corporate Social Responsibility di dalam laporan sustainability}

Berdasarkan pengujian yang telah dilakukan, hasil penelitian ini menunjukan bahwa variabel profitabilitas (ROE) memiliki thitung yaitu 3.562 dengan tingkat signifikansi sebesar 0,001 dan dapat dilihat juga nilai unstandardized coefficient beta sebesar 0.539. Dengan demikian hipotesis kelima $\left(\mathrm{H}_{5}\right)$ diterima, artinya profitabilitas berpengaruh terhadap pengungkapan Corporate Social Responsibility,. Alasan yang dapat digunakan adalah sampel perusahaan yang memiliki nilai profitabilitas yang diproksikan dengan ROE memiliki indeks pengungkapan pertanggungjawaban sosial di atas rata-rata dan mengungkapkan dengan cukup baik. 
Penelitian ini konsisten dengan hasil penelitian yang dilakukan oleh Sari et al. (2013), Santioso dan Chandra (2012), Sari (2014) serta Purnama et al. (2014), yang menyatakan bahwa semakin tinggi tingkat profitabilitas perusahaan maka semakin besar pula pengungkapan informasi sosialnya. Hal tersebut mengandung arti bahwa profitabilitas yang tinggi akan memberikan keyakinan perusahaan untuk melakukan pengungkapan tanggung jawab sosialnya dan perusahaan tetap akan mendapatkan keuntungan positif, yaitu mendapatkan legitimasi dari masyarakat yang pada akhirnya akan berdampak dengan meningkatnya keuntungan perusahaan dimasa yang akan datang (Sari, 2014:16).

Menurut Santioso dan Chandra (2012), profitabilitas yang tinggi akan mendorong para manajer untuk memberikan informasi yang terperinci, salah satunya yaitu pengungkapan CSR. Sebab, mereka ingin meyakinkan investor terhadap perusahaan agar para investor berinvestasi di perusahaan tersebut. Profitabilitas menunjukan efektifitas manajemen dalam menghasilkan laba. Laba perusahaan yang besar akan menuai banyak anggapan dari publik bahwa perusahaan hanya memperkaya para pemegang saham saja tanpa memperhatikan kesenjangan sosial yang ada di masyarakat. Dengan pengungkapan lebih banyak tentang aktivitas sosial maka akan menepis anggapan tersebut dan akan meningkatkan image perusahaan dimata masyarakat dan para investor . Dengan demikian peneliti menyimpulkan perusahaan yang memiliki profitabilitas yang tinggi akan mengungkapkan informasi CSR yang luas. Hal ini mungkin dikarenakan anggapan aktivitas CSR merupakan langkah strategis jangka panjang yang akan memberikan efek positif bagi perusahaan.

Hasil penelitian yang tidak mendukung penelitian ini yang di ungkapkan oleh Trisnawati (2014), Komalasari (2014), Sriayu dan Mimba (2013) yang menyatakan bahwa profitability tidak memiliki pengaruh terhadap corporate social responsibility disclosure. Hal ini didukung dengan argumentasi bahwa pada saat profitabilitas suatu perusahaan tinggi, maka pihak manajemen akan berasumsi bahwa menginformasikan hal-hal yang dapat mengganggu kesuksesan keuangan perusahaan tersebut tidak perlu dilakukan. Namun, saat perusahaan memiliki tingkat profitability yang rendah, maka perusahaan berharap para pengguna laporan akan membaca "good news" dari 
kinerja sosial dan lingkungan yang telah dilakukan oleh perusahaan (Sembiring, 2005:386).

\section{KESIMPULAN}

Berdasarkan hasil analisa dan pembahasan yang telah dilakukan terhadap permasalahan dengan menggunakan analisis regresi berganda, diperoleh beberapa kesimpulan sebagai berikut:

1. Hasil pengujian hipotesis pertama ditemukan bahwa variabel dewan komisaris independen $\left(\mathrm{X}_{1}\right)$ tidak berpengaruh signifikan terhadap pengungkapan corporate social responsibility di dalam laporan sustainability. Penelitian ini konsisten dengan penelitian Komalasari (2014), Sari (2014), Putri (2013). Namun penelitian ini tidak komsisten dengan penelitian Yesika (2013), Santioso dan Chandra (2012).

2. Hasil pengujian hipotesis kedua ditemukan bahwa variabel kepemilikan institusional $\left(\mathrm{X}_{2}\right)$ berpengaruh signifikan terhadap pengungkapan corporate social responsibility di dalam laporan sustainability. Penelitian ini konsisten dengan penelitian Purnama et al. (2014), Azhar (2014), Sari et al. (2013). Namun penelitian ini tidak konsisten dengan penelitian Maulidra (2015), Kusuma et al. (2014), Rustiarini (2010).

3. Hasil pengujian hipotesis ketiga ditemukan bahwa variabel kepemilikan asing $\left(\mathrm{X}_{3}\right)$ tidak berpengaruh signifikan terhadap pengungkapan corporate social responsibility di dalam laporan sustainability. Penelitian ini konsisten dengan penelitian Maulidra (2015), Kusuma et al. (2014), Sari (2014) dan Lovink (2013). Namun hasil penelitian ini tidak konsisten dengan penelitian Putri (2013), Sriayu dan Mimba (2013), Rustiarini (2010).

4. Hasil pengujian hipotesis keempat ditemukan bahwa variabel ukuran perusahaan $\left(\mathrm{X}_{4}\right)$ berpengaruh signifikan terhadap pengungkapan corporate social responsibility di dalam laporan sustainability. Penelitian ini konsisen dengan penelitian Trisnawati (2014), Komalasari (2014), Marina (2012). Namun hasil penelitian ini tidak konsisten dengan penelitian Oktariani (2014), Putri (2013), Sari et al. (2013)

5. Hasil pengujian hipotesis kelima ditemukan bahwa variabel profitabilitas $\left(\mathrm{X}_{5}\right)$ berpengaruh signifikan terhadap pengungkapan corporate social responsibility 
di dalam laporan sustainability. Penelitian ini konsisten dengan penelitian Purnama et al. (2014), Sari (2014), Sari et al. (2013) dan Santioso dan Chandra (2012). Namun asil penelitian ini tidak konsisten dengan penelitian Trisnawati (2014), Komalasari (2014), Sembiring (2005).

6. Secara simultan komposisi dewan komisaris independen, kepemilikan institusional, kepemilikan asing, ukuran perusahaan dan profitabilitas perusahaan berpengaruh signifikan terhadap pengungkapan corporate social responsibility di dalam laporan sustainability.

\section{REFERENSI}

Alijoyo, Antonius dan Suharto Zaini. 2004."Komisaris Independen Penggerak Praktik GCG di Perusahaan". Jakarta: PT. INDEKS Kelompok Gramedia

Anggraini, Fr. Retno. 2006. "Pengungkapan Informasi Sosial dan Faktor-faktor yang Mempengaruhi Pengungkapan Informasi Sosial dalam Laporan Keuangan Tahunan" SNA 9 Padang

Astuti, Dewi. 2004." Manajemen Keuangan Perusahaan". Jakarta : Ghalia Indonesia

Azhar, Al. 2014."Pengaruh Elemen Corporate Governance terhadap Luas Pengungkapan Corporate Social Responsibility". Jurnal Akuntansi, Vol. 3, No. 1, Oktober 2014 : $54-71$

Barkemeyer, Ralf. 2007. "Legitimacy as a Key Driver and Determinant of CSR in Developing Countries", Paper for the 2007 Marie Curie Summer School on Earth System Governance, Amsterdam University of St Andrews \& Sustainable Development Research Centre (SDRC) School of Management, Amsterdam, 28 May - 06 June.

Cahyaningsih dan Martina Venti Yustianti. 2011. "Pengaruh Mekanisme Corporate Governance dan Karakteristik Perusahaan Terhadap Pengungkapan Tanggungjawab Sosial. Jurnal Siasat Bisnis Vol. 15 No. 2, 171-186.

Chariri, Anis dan Imam Ghozali. 2007. Teori Akuntansi. Fakultas Ekonomi:Universitas Diponegoro Semarang.

Effendi, Muh. Arief. 2009. "The Power of Good Corporate Governance: Teori dan Implementasi". Salemba Empat, Jakarta. 
Emilsson, Classo dan Bredmar. 2012. “CSR and the quest for profitability-using Economic Value Added to trace profitability". International Journal of Economics and Management Sciences

Febriyana, Hana. 2013. "Pengaruh Ukuran Perusahan dan Mekanisme Corporate Goevernance Terhadap Nilai Perusahaan (Pada Perusahaan Manufaktur yang Go Public di Bursa Efek Indonesia). Jurnal UNP

Forum for Corporate Governance in Indonesia. 2004. “Corporate Governance Suatu Pengantar: Peranan Dewan Komisaris dan Komite Audit Dalam Pelaksanaan Corporate Governance", Jakarta

Ghozali, Imam, 2013. “Aplikasi Analisis Multivarite dengan SPSS” Edisi Keempat, Badan Penerbit Universitas Diponegoro, Semarang.

Global Reporting Initiative. "Sustainability Reporting"

https://www.globalreporting.org/information/sustainabilityreporting/Pages /default.aspx diakses pada 12 Januari 2015.

Hadi, Nor. 2011. “Corporate Social Responsibility”. Yogyakarta: Graha Ilmu.

Haniffa, R.M., dan T.E. Cooke. 2005. "The Impact of Culture and Governance on Corporate Social Reporting", Journal of Accounting and Public Policy 24, pp. 391-430.

Hermuningsih, Sri. 2013. "Profitability, Growth Opportunity, Capital Structure and The Firm Value". Journal University of Sarjanawiyata Tamansiswa Yogyakarta

Hikmah, N dan D. Rahmayanti, 2011. "Faktor-Faktor yang Mempengaruhi Luas Pengungkapan Corporate Governance dalam Laporan Tahunan Perusahaan Perbankan yang Terdaftar Di BEI". Simposium Nasional Akuntansi XIV

Hoje Jo, Maretno A. Harjoto. 2011. “The Causal effect CG on CSR” Jurnal Of Business Ethic

Jensen, Michael C dan Meckling, William H. 1976 ."Theory of the Firm: Managerial Behavior, Agency Costs and Ownership Structure," Journal of Financial Economics, October, V. 3, No. 4, pp. 305-360.

Kartini, Dwi. 2009 “Corporate Social Responsibility, Transformasi Konsep Sustainability Management dan Implementasi di Indonesia", PT Refika Aditama, Bandung. 
Khan, Md. H.U.Z., 2010. "The effect of corporate governance elements on corporate social responsibility (CSR) reporting", International Journal of Law and Management, Vol.52 No.2, pp.82-109.

Komalasari, Dessy dan Anna, Yane Devi. 2014, "Pengaruh Mekanisme Corporate Governance, Ukuran Perusahaan dan Profitabilitas Perusahaan Terhadap Corporate Social Responsibility (Studi Pada Perusahaan Perbankan yang Listing di Bursa Efek Indonesia Tahun 2008-2011)". Jurnal Akuntansi Institut Manejemen Telkom

Komite Nasional Kebijakan Governance. 2006. "Pedoman Umum Good Corporate Governance Indonesia". http://www.governance-indonesia.or.id. Diakses Tanggal 11 November 2014.

Kuncoro, Mudrajad. 2006."STRATEGI : bagaimana meraih keunggulan kompetitif". Jakarta: Erlangga.

Kusuma, Tanjung dan Darlis. 2014 "Pengaruh corporate governance dan karakteristik perusahaan terhadap luas pengungkapan corporate social responsibility (CSR) di dalam Sustainability Report". JOM FEKON Vol. 1 No.2 Oktober.

Lovink, Karina Angel Dwi,Etna NurAfri Yuyetta. 2013."Analisis Faktor-Faktor yang Mempengaruhi Pengungkapan Corporate Social Responsibility". Journal of Accounting UNDIP Volume 2, Nomor 2.

Santioso, Linda, dan Candra, Erline. 2012. "Pengaruh Profitabilitas, Ukuran Perusahaan, Leverage, Umur Perusahaan dan Dewan Komisaris Indpenden dalam Pengungkapan Corporate Social Responsibility”. Jurnal Fakultas Ekonomi Universitas Tarumanagara.

Maulidra, Hazra. 2015 "Pengaruh Struktur Kepemilikan Saham dan Leverage Terhadap Corporate Social Responsibility: Studi Empiris pada Perusahaan Manufaktur Yang Listing Di BEI 2010-2012”. Jurnal Akuntansi

Mursalim. 2007. "Simultanitas Aktivisme institusional, Struktur Kepemilikan, Kebijakan Dividen dan Utang dalam Mengurangi Konflik Keagenan". Makalah disampaikan pada Simposium Nasional Akuntansi X. Makasar.

Mursitama, Tirta N et.al. 2011. Corporate Social Responsibility (CSR) di Indonesia: Teori dan Implementasi Studi Kasus Community Development Riau Pulp. Jakarta: Institute for Development of Economics and Finance (INDEF). 
Novita dan Chaerul D. Djakman. 2008. Pengaruh Struktur Kepemilikan terhadap LuasPengungkapan Tanggung Jawab Sosial (CSR Disclosure) pada Laporan Tahunan Perusahaan;Studi Empiris pada Perusahaan Publik yang Tercatat di Bursa Efek Indonesia tahun 2006.Proceeding Simposium Nasional Akuntansi XI. Pontianak, 22-25 Juli.

Nurlela dan Islahudin. 2008. "Pengaruh Corporate Social Responsibility terhadap Nilai Perusahaan dengan Prosentase Kepemilikan Manajemen sebagai Variabel Moderating" Simposium Nasional Akuntansi XI

Oktariani, Ni Wayan dan Sri Harta Mimba Ni Putu. 2014." Pengaruh Karakteristik Perusahaan dab Tanggung Jawab Lingkungan Pada Pengungkapan Tanggung Jawab Sosial”. E-Jurnal Akuntansi Universitas Udayana 6.3:402-418

Purnama, Atmadja dan Darmawan. 2014. Pengaruh Size, Profitabilitas, Laverage dan Kepemilikan Institusional Terhadap Pengungkapan Tanggung Jawab Sosial Perusahaan (CSR Disclosure) dalam Laporan Tahunan Perusahaan Manufaktur Pada Bursa Efek Indonesia Periode 2010-2013. Volume: 2 No. 1 Tahun 2014

Putri, Chyinthia Dwi. 2013. "Pengaruh Corporate Governance dan Karakteristik Perusahaan Terhadap Pengungkapan Tanggung Jawab Sosial Perusahaan di dalam Suatainability Report (Studi Empiris Perusahaan yang Terdaftar di BEI) “. Jurnal UNP

Ratnasari, Yunita. 2011."Pengaruh Corporate Governance Terhadap Luas Pengungkapan Tanggung Jawab Sosial Perusahaan di dalam Sustainability Report”. Jurnal Akuntansi UNDIP.

Rustiarini, Ni Wayan. 2010. "Pengaruh Struktur Kepemilikan Saham terhadap Pengungkapan Corporate Sosial Responsibility", Simposium Nasional Akuntansi XIII.Purwokerto,

Sari, Sutrisno, dan Sukuharsono., 2013."Pengaruh Kepemilikan Institusional, Komposisi Dewan Komisaris, Kinerja Perusahaan terhadap Luas Pengungkapan Corporate Social Responsibility di dalam Sustainability Report pada Perusahaan Manufaktur yang Terdaftar di BEI". Jurnal Aplikasi Manajemen, Vol. 11 No. 3.

Sari, Lian Permata. 2014."Pengaruh Profitabilitas, Proporsi Dewan Komisaris Independen dan Kepemilikan Saham Asing Terhadap Pengungkapan Corporate 
Social Responsibility: Study Empiris pada Perusahaan yang tercatat di Bursa Efek Jakarta.". Jurnal Akuntansi.

Sayekti, Yosefa. Wondabi, Ludovicus Sensi., 2007. "Pengaruh CSR Disclosure Terhadap Earning Response Coefficient", Simposium Nasional Akuntansi (SNA), Vol. X.

Sekaran, Uma. 2006."Research Method for Business-Metodologi Penelitian untuk Bisnis". Edisi Ke-empat. Jakarta: Salemba Empat

Sembiring, Eddy Rismanda. 2005." Karakteristik Perusahaan dan Pengungkapan Tanggung Jawab Sosial: Study Empiris pada Perusahaan yang tercatat di Bursa Efek Jakarta." Simposium Nasional Akuntansi VIII. Solo, 15-16 September 2005.

Setyarini, Yulia \& Paramitha, Melvie. 2011. Pengaruh Mekanisme Good Corporate Governance terhadap Corporate Social Responsibility. Jurnal Kewirausahaan Vol. 5 No.

2 , Desember 2011. ISSN. 1978-4724.

Sriayu dan Mimba. 2013. "Pengaruh Karakteristik Perusahaan Terhadap Corporate Social Resposibility Disclosure". E-Jurnal Akuntansi Udayana 5.

Sudana, I Made dan Putu Ayu Arlindania. 2011."Corporate Governance dan Pengungkapan Corporate Social Responsibility pada Perusahaan Go-Public di Bursa Efek Indonesia”. Jurnal Manajemen Teori dan Terapan, Tahun 4, No. 1

Supomo, Bambang \& Nur Indriantoro. 2002.“Metodologi Penelitian Bisnis, untuk Akuntansi dan Manajemen". Edisi 1, BPFE Yogyakarta

Surya, Indra \& Yustiavandana, Ivan. 2006. "Penerapan Good Corporate Governance: Mengesampingkan Hak-hak Istimewa Demi Kelangsungan Usaha". Jakarta : Prenada Media Group.

Terzaghi, Muhammad Titan. 2012. "Pengaruh Earning Management dan Mekanisme Corporate Governance Terhadap Pengungkapan Tanggung Jawab Sosial Perusahaan Manufaktur yang Terdaftar di Bursa Efek Indonesia". Jurnal Ekonomi dan Informasi Akuntansi (JENIUS) Vol.2 No. 1 Januari 2012.

Trisnawati, 2014 "Pengaruh Ukuran Perusahaan, Profitabilitas, Leverage Ukuran Dewan Komisaris dan Kepemilikan Manajerial Terhadap Pengungkapan Corporate Social Responsibility (CSR) Industri Perbankan di Indonesia”. Seminar Nasional Dan Call For Paper FEB UMS. 
| FAKTOR-FAKTOR YANG MEMPENGARUHI PENGUNGKAPAN CORPORATE...

Ucuy, 2015." Lagi, Perusahaan Besar Sawit Hilang Dari Peta Dinas Perkebunan". (http://readersblog.mongabay.co.id/rb/2015/01/30/lagi-perusahaan-besarsawit-hilang-dari-peta-dinas-perkebunan.

Walpole, Ronald.E. 1982, “ Pengantar Statistika: Edisi 3”. Jakarta : PT.Gramedia Puataka Utama 